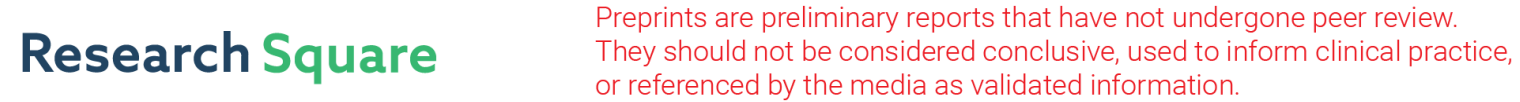 \\ The Comparison of the Effects of B-Cyclodextrin Complex and Derivative Complex with Silver Nanoparticles on Cotton Fabric
}

\section{CAGLA SARI}

Pamukkale University, Textile Engineering Department

BUKET ARIK ( $\sim$ barik@pau.edu.tr)

Pamukkale University, Engineering Faculty, Textile Engineering Department https://orcid.org/00000003-0647-5851

\section{Research Article}

Keywords: $\beta$-cyclodextrin, sulfated $\beta$-cyclodextrin, antibacterial textile, inclusion complex, silver nanoparticles

Posted Date: July 15th, 2021

DOI: https://doi.org/10.21203/rs.3.rs-693021/v1

License: (9) (i) This work is licensed under a Creative Commons Attribution 4.0 International License. Read Full License 


\title{
THE COMPARISON OF THE EFFECTS OF $\beta$-CYCLODEXTRIN COMPLEX AND DERIVATIVE COMPLEX WITH SILVER NANOPARTICLES ON COTTON FABRIC
}

\author{
Cagla SARI, Buket ARIK*
}

\author{
Pamukkale University, Faculty of Engineering, Textile Engineering Department, Denizli, TURKEY \\ * Corresponding author: Buket ARIK (Email: barik@pau.edu.tr)
}

\begin{abstract}
In this study, sulfated $\beta$-cyclodextrin (S- $\beta$-CD) which is a $\beta$-cyclodextrin derivative was obtained by chemical treatment of natural $\beta$-cyclodextrin $(\beta-C D)$ with sulfuric acid. Afterwards, $\beta-C D$ and S- $\beta$-CD were applied to cotton fabrics. In different treatments, $\beta-C D$ and S- $\beta$-CD were bonded to cotton fabrics with EDTA crosslinking agent. Then, all the fabrics were treated with antibacterial agent silver nanoparticles (AgNPs) and inclusion complexes were formed. The aims of this study were to increase the washing stability and the antibacterial activity against microorganisms and to compare the effects of $\beta-\mathrm{CD}$ complex and derivative complex with silver nanoparticles on treated cotton samples. So, for this purpose, the properties of the treated samples like antibacterial activity, washing stability, add-on, tensile strength, handle, thickness and color change were tested and compared to each other. In addition, characterization analyzes such as SEM, EDX and FT-IR were performed on the samples and XRD analysis was performed to characterize the AgNPs. As a result of the study, it was observed that AgNPs alone were not sufficient to obtain antibacterial textiles with strong antibacterial effect and good washing stability. The inclusion complexes formed with $\beta-\mathrm{CD}$ and S- $\beta-\mathrm{CD}$ had much more effective antibacterial activity and more robust washing stability. In addition, when the physical properties except stiffness and yellowness were considered besides antibacterial activity and washing stability, the treatment of derivative $\beta$-CD complex with AgNPs and crosslinking this complex to cotton sample by means of EDTA was found to be the most favorable method.
\end{abstract}

Keywords: $\beta$-cyclodextrin, sulfated $\beta$-cyclodextrin, antibacterial textile, inclusion complex, silver nanoparticles

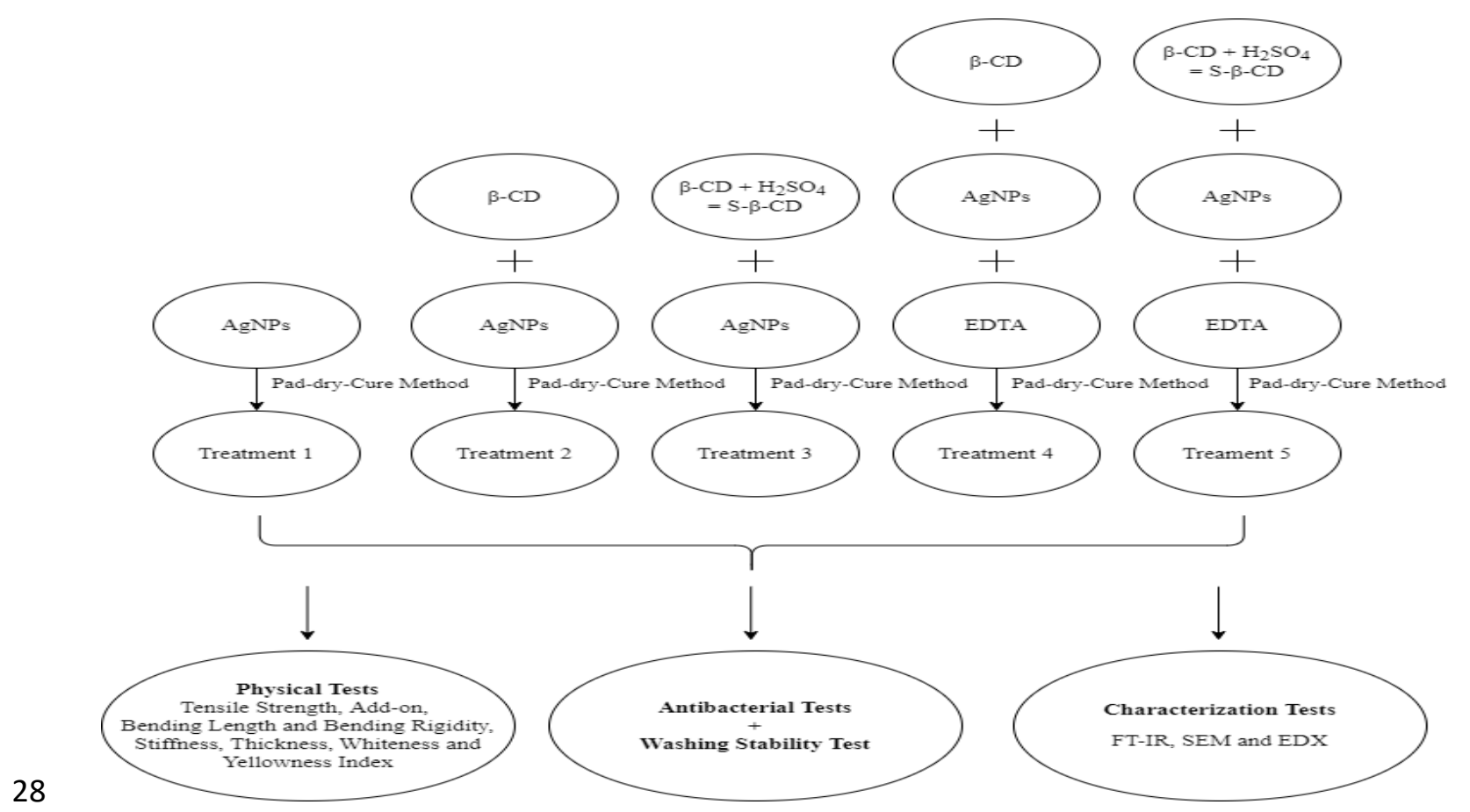


Textile products have long been known as susceptible media that support the growth and reproduction of microorganisms such as bacteria and fungi. These microorganisms are found almost everywhere in the environment and can multiply rapidly when basic requirements such as moisture, nutrients and temperature are met (Gao and Cranston 2008; Abdel-Halim et al. 2011; El-Shishtawy et al. 2011; Shahidi and Wiener 2012; Butola and Mohammad 2016; Vhanbatte et al. 2017; Eid et al. 2020; Arik 2021). Therefore, it is of great importance that the fabrics to form a protection shield and protect them from all kinds of microbial attacks (El-Shishtawy et al. 2011; Shahidi and Wiener 2012; Butola and Mohammad 2016; Eid et al. 2020; Ogunsona et al. 2020; Salem et al. 2020; Arik 2021). There are many antibacterial agents that kill or inhibit the growth of microorganisms. However, most of these agents can be toxic to humans and the environment during application. For this reason, the antibacterial agent to be used in the textile industry should not only kill microorganisms, but also be safe for humans and the environment and not adversely affect the other properties of the textile materials (Gao and Cranston 2008; Bozaci et al. 2015; Butola and Mohammad 2016; Ibrahim and Hassan 2016; Vhanbatte et al. 2017; Nogueira 2018; Ogunsona et al. 2020; Arik 2021). Due to be biocompatible and non-toxic and have strong antibacterial effect and high thermal stability, silver is generally preferred over other compounds (Gao and Cranston 2008; Rai et al. 2009; George et al. 2010; Jaiswal et al. 2010; Ravindra et al. 2010; Andrade et al. 2014; Bozaci et al. 2015; Butola and Mohammad 2016; Salem et al. 2020). The antibacterial property of silver is directly related to the amount of silver and the ability of the amount of silver released to inactivate target bacteria and fungal cells. Ionized silver is highly effective in antibacterial sense since it binds to tissue proteins, creates structural deformations in the bacterial cell wall and cell membrane through ionic interaction, and causes cell degradation and even death (Gao and Cranston 2008; Rai et al. 2009; El-Shishtawy et al. 2011; Hebeish et al. 2014a; Bozaci et al. 2015; Butola and Mohammad 2016; Ibrahim and Hassan 2016; Vhanbatte et al. 2017; Ogunsona et al. 2020; Arik 2021). On the other hand, it has been reported that when silver is used as nanoparticles, it gives some extra advantages like good and uniform dispersion without agglomeration on the textile surface and high affinity and interaction with microorganisms thanks to their large surface area to volume ratio and high surface energy (Rai et al. 2009; Jaiswal et al. 2010; Ravindra et al. 2010; Sathiya Priya et al. 2013; Andrade et al. 2014; Hebeish et al. 2014a; Bozac1 et al. 2015; Butola and Mohammad 2016; Ibrahim and Hassan 2016; Vhanbatte et al. 2017; Ru et al. 2018; Eid et al. 2020; Ogunsona et al. 2020; Arik 2021). Although the silver has a considerable antibacterial activity, in order to be washing durable and longly effective, silver particles should have high bonding performance and controlled release mechanism on the surface of the textile materials (Butola and Mohammad 2016; Arik 2021). For this aim, alternative methods like nanocomposite formation (Bozaci et al. 2015), crosslinking (Nogueira 2018; Ru et al. 2018), capsulation (George et al. 2010; Malini et al. 2020) and complexation (Jaiswal et al. 2010; Popescu et al. 2013; Sathiya Priya et al. 2013; Andrade et al. 2014) have been suggested.

Cyclodextrins are obtained by enzymatic degradation of starch that results in a mixture of $\alpha-, \beta-, \gamma$-cyclodextrins and acyclic dextrins (Del Valle 2004; Szejtli 2004; Grigoriu et al. 2008; Abdel-Halim et al. 2011; Arslan 2012; Szejtli 2013; Hebeish et al. 2014b; Popr 2016; Setthayanond et al. 2017; Carneiro et al. 2019). Cyclodextrins are white, odorless, sweet, crystalline powders and do not absorb moisture (Arslan 2012; Crini 2014). In addition, they are as stable as starch or sugar and can be stored for years without spoiling (Arslan 2012). Cyclodextrins seem to be a truncated cone and have a ring structure. There are three types of cyclodextrins based on the number of glycopyranose bonds as alpha $(\alpha)$ cyclodextrin, beta $(\beta)$ cyclodextrin and gamma $(\gamma)$ cyclodextrin and each cyclodextrin unit has a cavity that can act as a host for a guest (Del Valle 2004; Szejtli 2004; Ammayappan and Moses 2009; Jaiswal et al. 2010; Abdel-Halim et al. 2011; Bhaskara-Amrit et al. 2011; Arslan 2012; Sathiya Priya et al. 2013; Andrade et al. 2014; Popr 2016; Radu et al. 2016; Carneiro et al. 2019). Even though $\beta$-cyclodextrin $(\beta-C D)$ is the least water soluble, due to the simple production method, medium cavity diameter and low price, it is the most commercially produced type of the three natural cyclodextrins (Del Valle 2004; Abdel-Halim et al. 2011; Bhaskara-Amrit et al. 2011; Andrade et al. 2014; Popr 2016). Cyclodextrins can form an inclusion complex (guest-host structure) with aromatic compounds or various antibacterial agents thanks to Van der Waals forces, hydrogen bonding and hydrophobic interactions (Del Valle 2004; Ammayappan and Moses 2009; George et al. 2010; Jaiswal et al. 2010; Abdel-Halim et al. 2011; Bhaskara-Amrit et al. 2011; Arslan 2012; Sathiya Priya et al. 2013; Szejtli 2013; Hebeish et al. 2014b; Popr 2016). On the other hand, natural cyclodextrins for instance $\beta$-CDs 
have a limited solubility in most commonly used solvents and water since the hydroxyl groups in the cyclodextrin molecule form hydrogen bonds with each other (Del Valle 2004; Szejtli 2004; Bhaskara-Amrit et al. 2011; Arslan 2012; Popr 2016; Radu et al. 2016). So, in order to increase the solubility of natural cyclodextrins and the interaction of cyclodextrins with the guest molecule, derivatization possibilities of cyclodextrins have been studied. In derivatization reactions, some groups have been connected to the cyclodextrin structure and by this way, functional properties like solubility, stability and reactivity can be changed. In addition, more controlled and durable inclusion complexes against physical abrasion and washing can be obtained (Del Valle 2004; Szejtli 2004; Bhaskara-Amrit et al. 2011; Arslan 2012; Szejtli 2013; Popr 2016; Radu et al. 2016; Rezanka 2018). By inserting guest molecules into the cyclodextrin spaces attached to the fiber surface, the properties of the textile material can be changed. By this way, the finished textile material turns into a UV protective, insect repellent, antibacterial effective, bad odor catching, fragrance releasing material (perfume effect) (Szejtli 2003; Grigoriu et al. 2008; Ammayappan and Moses 2009; Bhaskara-Amrit et al. 2011; Sundrarajan and Rukmani 2012; Popescu et al. 2013; Radu et al. 2016; Setthayanond et al. 2017; Carneiro et al. 2019). Moreover, they possess controlled release mechanism that can be longly durable (Radu et al. 2016).

There are a lot of studies about silver nanoparticles that give considerable antibacterial activity to textile materials and formation of inclusion complexes between cyclodextrin and silver nanoparticles. Jaiswal et al. 2010 formed an inclusion complex between the silver nanoparticles (AgNPs) and $\beta$-cyclodextrins and the antibacterial activities of the complexes against E. coli, P. Aeruginosa and $S$. aureus bacteria were tested by agar diffusion methods. They found that the use of silver nanoparticles with $\beta$-cyclodextrin complex was more effective than the use of silver nanoparticles alone. George et al. 2010 synthesized silver nanoparticles and encapsulated them into the $\beta$ cyclodextrin and found efficient antibacterial activity against $P$. Aeruginosa, S. aureus, S. marcescens, E. coli and K.pneumoniae. Sathiya Priya et al. 2013 formed an inclusion complex with silver nanoparticles (AgNPs) with three different $\beta$-cyclodextrin solutions as 5,10 and $15 \mathrm{mM}$ and examined the antibacterial effect of the prepared complex against $S$. aureus bacteria. They observed that the antibacterial effect of $\beta$-cyclodextrins complexed with silver nanoparticles was higher than the non-complexed silver nanoparticles. In addition, it was observed that this antibacterial activity increased as the concentration of $\beta$-cyclodextrin increased. But, the use of cyclodextrin derivatives and the comparison of the effects of natural cyclodextrin and derivative cyclodextrin on textiles have not been studied in detail. Aubert-Viard et al. 2019 designed a wound dressing consisting of methylated $\beta$ cyclodextrin and chitosan molecules and found an effective antibacterial activity against gram positive (S. aureus) and gram negative (E. coli) bacteria for several weeks. Popescu et al. 2013 formed a complex with monochlorotriazine- $\beta$-cyclodextrin (MCT- $\beta$-CD) with silver nanoparticles and enabled these complexes to be transferred to cellulosic fabric. They observed that fabrics treated with silver nanoparticles complexed with MCT$\beta$-CD had strong antibacterial activity against $E$. coli and $S$. aureus bacteria. Selvam et al. 2012 obtained sulfated$\beta$-cyclodextrin as a result of the chemical treatment of $\beta$-cyclodextrin with sulfuric acid. Then sulfated- $\beta$ cyclodextrin was complexed with different metal nanoparticles and bound to cotton fabric with crosslinker, EDTA. They reported sulfated- $\beta$-cyclodextrin was important for biomedical applications in textile but they did not investigate the physical properties of cotton in detail.

In this study, silver nanoparticles (AgNPs) were used as an antibacterial agent and inclusion complexes between $\beta$-cyclodextrin and its derivative (sulfated $\beta$-cyclodextrin) with silver nanoparticles were formed and applied to cotton fabrics with and without cross-linking chemical (EDTA) by pad-dry-cure method. EDTA was selected due to its chelating ability towards metal ions and binding ability towards cyclodextrins. In order to compare the effects of the treatments, physical tests, antibacterial tests and characterization tests were applied to the cotton fabrics.

\section{Experimental}

\section{Materials}

Desized and bleached woven $100 \%$ cotton fabric with a weight of $245 \mathrm{~g} / \mathrm{m}^{2}$ was used in the study. Warp yarn density was 45 threads $/ \mathrm{cm}$ and weft yarn density was 20 threads $/ \mathrm{cm}$.

The properties and supplier information of the chemicals used in the study are given in Table 1. 
Table 1. The properties and supplier information of the chemicals

\begin{tabular}{l|l}
\hline Chemicals & Properties and supplier information \\
\hline$\beta$-cyclodextrin & $1135 \mathrm{~g} /$ mole, Roquette (Kleptose) \\
\hline Sulfuric Acid $\left(\mathrm{H}_{2} \mathrm{SO}_{4}\right)$ & $95 \%-98 \%$, Tekkim \\
\hline Calcium Carbonate $\left(\mathrm{CaCO}_{3}\right)$ & $98 \%, 100.09 \mathrm{~g} /$ mole, Aromel Chemistry \\
\hline Ethyl Alcohol $\left(\mathrm{C}_{2} \mathrm{H}_{5} \mathrm{OH}\right)$ & $96 \%$, Merck \\
\hline Silver Nanoparticles $(\mathrm{AgNPs})$ & $99.99 \%$, Nanografi \\
\hline EDTA (Titriplex III) & $292.25 \mathrm{~g} /$ mole, Emir Chemistry \\
\hline
\end{tabular}

127

128

129

130

131

132

133

134

135

136

137

138

139

140

141

142

143

144

145

Methods

\section{Preparation of $\beta$-cyclodextrin derivative (Sulfated $\beta$-cyclodextrin)}

The $\beta$-cyclodextrin derivative (sulfated $\beta$-cyclodextrin) was prepared in accordance with the method specified by preceding studies (Yang 2009; Selvam et al. 2012). Firstly, $10 \mathrm{~g}$ of $\beta$-cyclodextrin and $3 \mathrm{~mL}$ of sulfuric acid mixture was kept at $0-5^{\circ} \mathrm{C}$ for $2 \mathrm{~h}$ in an ice bath. Then, $1 \mathrm{~N}$ calcium carbonate solution was added to this mixture and filtered. After filtering, $95 \%$ ethanol was added to the particles and kept at $0-5{ }^{\circ} \mathrm{C}$ overnight. The ethanol in the solution was filtered and the particles were dried in the oven at $110^{\circ} \mathrm{C}$ for about $45 \mathrm{~min}$.

\section{Finishing treatments}

Five different finishing treatments were studied and four of these were carried out in two steps. These treatments are application of $\beta$-cyclodextrin, sulfated $\beta$-cyclodextrin with and without crosslinking agent EDTA in the first step and application of silver nanoparticles (AgNPs) to form inclusion complexes on the cotton surface in the second step. On the other hand, only for treatment 1 that was used as a reference, silver nanoparticles were applied to cotton surface alone in other words without complexation in one step.

The details of the finishing treatment recipes are given in Table 2.

Table 2. The details of the finishing treatment recipes

\begin{tabular}{c|c|c}
\hline Finishing treatments & First step & Second step \\
\hline Treatment 1 & $50 \mathrm{mg} / \mathrm{L} \mathrm{AgNPs}$ & - \\
\hline Treatment 2 & $50 \mathrm{~g} / \mathrm{L} \beta$-cyclodextrin & $50 \mathrm{mg} / \mathrm{L} \mathrm{AgNPs}$ \\
\hline Treatment 3 & $50 \mathrm{~g} / \mathrm{L} \mathrm{Sulfated} \beta$-cyclodextrin & $50 \mathrm{mg} / \mathrm{L} \mathrm{AgNPs}$ \\
\hline Treatment 4 & $50 \mathrm{~g} / \mathrm{L} \beta$-cyclodextrin $+5 \mathrm{~g} / \mathrm{L}$ EDTA & $50 \mathrm{mg} / \mathrm{L} \mathrm{AgNPs}$ \\
\hline Treatment 5 & $50 \mathrm{~g} / \mathrm{L}$ Sulfated $\beta$-cyclodextrin $+5 \mathrm{~g} / \mathrm{L}$ EDTA & $50 \mathrm{mg} / \mathrm{L} \mathrm{AgNPs}$ \\
\hline
\end{tabular}

All the solutions were prepared as $300 \mathrm{~mL}$, stirred and their $\mathrm{pH}$ values were determined as shown in Table 3 .

Table 3. $\mathrm{pH}$ values of the solutions

\begin{tabular}{l|c}
\hline Solutions & pH values \\
\hline Solution 1: Distilled Water + AgNPs & 5 \\
\hline Solution 2: Distilled Water + $\beta$-CD & 5 \\
\hline Solution 3: Distilled Water + S- $\beta$-CD & 11 \\
\hline Solution 4: Distilled Water + $\beta$-CD + EDTA & 10 \\
\hline Solution 5: Distilled Water + S- $\beta$-CD + EDTA & 12 \\
\hline
\end{tabular}

Then the cotton samples were dipped into these solutions for $15 \mathrm{~min}$. and padded by a $90 \%$ wet pick-up in the laboratory type padding machine (Prowhite/Y002). After padding, they were dried at $80^{\circ} \mathrm{C}$ for 5 min. and cured at $140^{\circ} \mathrm{C}$ for $3 \mathrm{~min}$. by the laboratory type stenter machine (Prowhite/Y003). In the second step, pad-dry-cure 150 
In order to test the washing stability of the antibacterial treatment, all the samples were washed for once with a 5 $\mathrm{g} / \mathrm{L}$ granular soap at $60^{\circ} \mathrm{C}$ for $30 \mathrm{~min}$. in accordance with the ISO $105 \mathrm{C} 03$ standard. Then, the unwashed and washed samples were sent to antibacterial test. From the antibacterial test results, it was understood that this washing conditions were quite hard compared to household washing conditions. Therefore, the washing standard was changed in the second part of the study and the most antibacterial effective sample was washed at household washing conditions as $40^{\circ} \mathrm{C}$ for 1,5 and 10 times in accordance with ISO $105 \mathrm{C} 01$ standard. The washing processes were carried out by SDL ATLAS/M228 machine.

\section{Antibacterial activity}

The antibacterial activity tests of the samples against Staphylococcus aureus (ATCC 29213, gram-positive bacteria) and Escherichia coli (ATCC 25922, gram-negative bacteria) were carried out quantitatively according to the AATCC 100 method. The reduction (\%) in the number of living microorganism was calculated from the number of living microorganism present in the medium containing sample according to the Eq. 1 .

$$
\text { Reduction }(\%)=\left[\frac{A-B}{A}\right] \times 100
$$

where $\mathrm{A}$ is the number of living microorganism ( $\mathrm{CFU} / \mathrm{mL}$, colony forming units per milliliter) of control sample after $24 \mathrm{~h}$ and $\mathrm{B}$ is the number of living microorganism $(\mathrm{CFU} / \mathrm{mL})$ of treated sample after $24 \mathrm{~h}$.

\section{Physical tests}

\section{Add-on calculation}

The add-on values of the treated cotton samples were calculated according to Eq. 2.

$$
W_{\text {add-on }}(\%)=\left[\frac{W_{2}-W_{1}}{W_{1}}\right] \times 100
$$

where $\mathrm{W}_{1}$ is the weight of the untreated fabric sample and $\mathrm{W}_{2}$ is the weight of the treated fabric samples. Each sample was measured three times and average values were calculated. The add-on percentage values (\%) of treated fabric samples were given.

\section{Tensile strength measurement}

The tensile strength and elongation at break values of the samples were measured in SDL Atlas H10KT test machine, according to the strip method of TS EN ISO 13934-1. Each sample was measured three times and average values were calculated.

\section{Bending length and bending rigidity measurement}

The bending length of the fabric samples were measured by SDL Atlas/M003B in order to determine the handle properties according to TS 1409 standard. Each sample was measured three times and average values were calculated. Bending rigidity was calculated according to Eq. 3 .

$$
G=0.1 \times W \times L^{3}
$$

where $\mathrm{G}$ is the bending rigidity, $\mathrm{W}$ is the fabric weight and $\mathrm{L}$ is the bending length. General bending rigidity was calculated according to Eq. 4.

$$
G_{0}=\left[G_{w e} \times G_{w a}\right]^{1 / 2}
$$

where $\mathrm{G}_{0}$ is the general bending rigidity, Gwe is the average bending rigidity in weft direction and Gwa is the average bending rigidity in warp direction. 
The stiffness of the fabric samples were measured by Prowhite Pneumatic Stiffness Tester in order to determine the handle properties according to ASTM D4032 standard. Each sample was measured four times and average values were calculated.

\section{3}

194

195

196

197

198

199

200

201

202

\section{Thickness measurement}

The thickness values of the fabric samples were measured by Louis Schopper Automatic Micrometer. Each sample was measured four times and average values were calculated.

\section{Whiteness and yellowness index measurement}

Whiteness and yellowness index values of the fabric samples were measured by DataColor 600TM Spectrophotometer and the results were given as Stensby whiteness index and E313 yellowness index values, respectively. Each sample was measured five times and average values were calculated.

\section{Characterization analyses}

\section{Fourier transform infrared spectroscopy (FT-IR) analysis}

Fourier transform infrared spectroscopy (FT-IR) analyses of $\beta$-CD and sulfated $\beta$-CD powders were performed by Thermo Nicolet iS50 with a diamond universal ATR (Attenuated Total Reflectance) accessory in ATR mode. The diamond crystal giving an effective depth of penetration of 1 micron and at a resolution of $4 \mathrm{~cm}^{-1}$ was used. The measurement was carried out in the region from 4000 to $400 \mathrm{~cm}^{-1}$ and recorded spectrum for each sample was the average of 4 scans.

\section{Scanning electron microscopy (SEM) analysis}

The surface morphologies of the cotton fabrics were examined by using Scanning Electron Microscope (SEM) in Zeiss Supra 40VP device with x5000 magnification range. Before the analysis, the fabric samples were coated with gold and palladium $(\mathrm{Au}+\mathrm{Pd})$ for $6 \mathrm{~min}$. by Quorum Q150R ES device to increase the conductivity of the fabrics.

\section{Energy dispersive $x$-ray $(E D X)$ analysis}

Energy dispersive X-ray analysis (EDX) of treated and untreated fabric samples were also performed in Zeiss Supra 40VP device and the atomic percentage (\%) values of silver nanoparticles deposited on the surface of the samples were detected for each treatment.

\section{$X$-ray diffraction $(X R D)$ analysis}

The X-ray diffraction (XRD) analysis of the silver nanoparticles was recorded using GNR APD PRO 2000 X-ray diffractometer $(\mathrm{CuK} \alpha)$ radiation, $\left(\lambda=1.54059 \mathrm{~A}^{\circ}\right)$, the diffraction peaks were obtained in $2 \theta$ degree angle, ranging from $30^{\circ}$ to $80^{\circ}$. Crystallite size of the nanoparticles was calculated using full width at half maximum (FWHM) of the $100 \%$ peak of nanoparticles in Debye-Scherrer's equation (Eq. 5),

$$
D=\frac{k \lambda}{\beta \operatorname{Cos} \theta}
$$

where $\mathrm{D}$ is the mean particle size $(\mathrm{nm}), \lambda$ is X-ray wavelength $\left(\lambda=1.54059 \mathrm{~A}^{\circ}\right), \beta$ is FWHM of the diffraction line, $\theta$ is diffraction angle, and $\mathrm{k}$ is constant which assumed as 0.94 . 


\section{Antibacterial activity test results}

The antibacterial activity results of the treated fabrics against $S$. aureus are shown in Table 4 and Figure 1 . The antibacterial activity results of the treated fabrics against $E$. coli bacteria are shown in Table 5 and Figure 2.

Table 4. The antibacterial activity results of the treated fabrics against $S$. aureus

\begin{tabular}{|c|c|c|c|c|c|c|}
\hline \multirow{2}{*}{ Treatment } & \multicolumn{2}{|c|}{$\begin{array}{c}\text { Bacterial count before } \\
\text { washing }\end{array}$} & \multicolumn{2}{|c|}{$\begin{array}{l}\text { Bacterial count after } \\
\text { washing at } 60^{\circ} \mathrm{C}\end{array}$} & \multicolumn{2}{|c|}{$\begin{array}{c}\text { Bacterial reduction } \\
(\%)\end{array}$} \\
\hline & $\begin{array}{c}\text { Control } \\
\text { sample } \\
\text { after } 24 \mathrm{~h}\end{array}$ & $\begin{array}{c}\text { Treated } \\
\text { sample } \\
\text { after } 24 \mathrm{~h}\end{array}$ & $\begin{array}{c}\text { Control } \\
\text { sample } \\
\text { after } 24 \mathrm{~h} \\
\end{array}$ & $\begin{array}{c}\text { Treated } \\
\text { sample } \\
\text { after } 24 \mathrm{~h}\end{array}$ & $\begin{array}{c}\text { Before } \\
\text { washing }\end{array}$ & $\begin{array}{c}\text { After } \\
\text { washing }\end{array}$ \\
\hline $\begin{array}{l}\text { Treatment } 1 \\
\text { (AgNPs) }\end{array}$ & 560.000 & 290.000 & 560.000 & 400.000 & 48.21 & 28.57 \\
\hline $\begin{array}{l}\text { Treatment } 2 \\
(\beta-C D+A g N P s)\end{array}$ & 560.000 & 260.000 & 560.000 & 310.000 & 53.57 & 44.64 \\
\hline $\begin{array}{l}\text { Treatment } 3 \\
(\mathrm{~S}-\beta-\mathrm{CD}+\mathrm{AgNPs})\end{array}$ & 560.000 & 38.000 & 560.000 & 280.000 & 93.21 & 50.00 \\
\hline $\begin{array}{l}\text { Treatment } 4 \\
(\beta-C D+\text { AgNPs }+ \text { EDTA })\end{array}$ & 560.000 & 188.000 & 560.000 & 263.000 & 66.43 & 53.04 \\
\hline $\begin{array}{l}\text { Treatment } 5 \\
(\mathrm{~S}-\beta-\mathrm{CD}+\mathrm{AgNPs}+\mathrm{EDTA})\end{array}$ & 560.000 & 28.000 & 560.000 & 220.000 & 95.00 & 60.71 \\
\hline
\end{tabular}

232

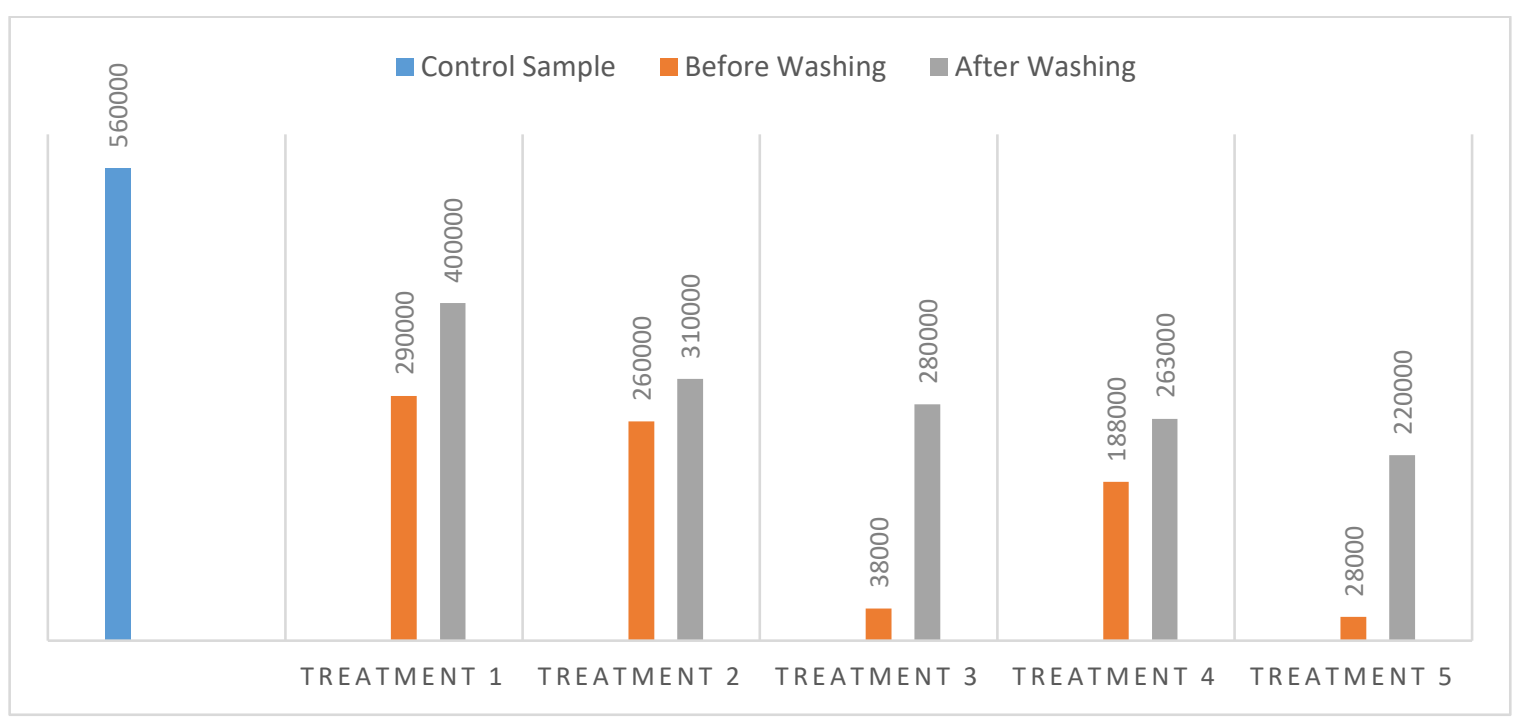

Figure 1. The antibacterial activity results of the treated fabrics against $S$. aureus 
Table 5. The antibacterial activity results of the treated fabrics against E. coli

\begin{tabular}{|c|c|c|c|c|c|c|}
\hline \multirow{2}{*}{ Treatment } & \multicolumn{2}{|c|}{$\begin{array}{c}\text { Bacterial count before } \\
\text { washing }\end{array}$} & \multicolumn{2}{|c|}{$\begin{array}{l}\text { Bacterial count after } \\
\text { washing at } 60^{\circ} \mathrm{C}\end{array}$} & \multicolumn{2}{|c|}{$\begin{array}{c}\text { Bacterial reduction } \\
(\%)\end{array}$} \\
\hline & $\begin{array}{c}\text { Control } \\
\text { sample } \\
\text { after } 24 \mathrm{~h}\end{array}$ & $\begin{array}{c}\text { Treated } \\
\text { sample } \\
\text { after } 24 \mathrm{~h}\end{array}$ & $\begin{array}{c}\text { Control } \\
\text { sample } \\
\text { after } 24 \mathrm{~h}\end{array}$ & $\begin{array}{c}\text { Treated } \\
\text { sample } \\
\text { after } 24 \mathrm{~h}\end{array}$ & $\begin{array}{c}\text { Before } \\
\text { washing }\end{array}$ & $\begin{array}{c}\text { After } \\
\text { washing }\end{array}$ \\
\hline $\begin{array}{l}\text { Treatment } 1 \\
\text { (AgNPs) }\end{array}$ & 590.000 & 390.000 & 590.000 & 560.000 & 33.90 & 5.08 \\
\hline $\begin{array}{l}\text { Treatment } 2 \\
(\beta-C D+A g N P s)\end{array}$ & 590.000 & 250.000 & 590.000 & 530.000 & 57.63 & 10.17 \\
\hline $\begin{array}{l}\text { Treatment } 3 \\
(\mathrm{~S}-\beta-\mathrm{CD}+\mathrm{AgNPs})\end{array}$ & 590.000 & 102.000 & 590.000 & 430.000 & 82.71 & 27.12 \\
\hline $\begin{array}{l}\text { Treatment } 4 \\
(\beta-C D+A g N P s+\text { EDTA })\end{array}$ & 590.000 & 225.000 & 590.000 & 360.000 & 61.86 & 38.98 \\
\hline $\begin{array}{l}\text { Treatment } 5 \\
(\mathrm{~S}-\beta-\mathrm{CD}+\mathrm{AgNPs}+\mathrm{EDTA})\end{array}$ & 590.000 & 28.000 & 590.000 & 280.000 & 95.25 & 52.54 \\
\hline
\end{tabular}

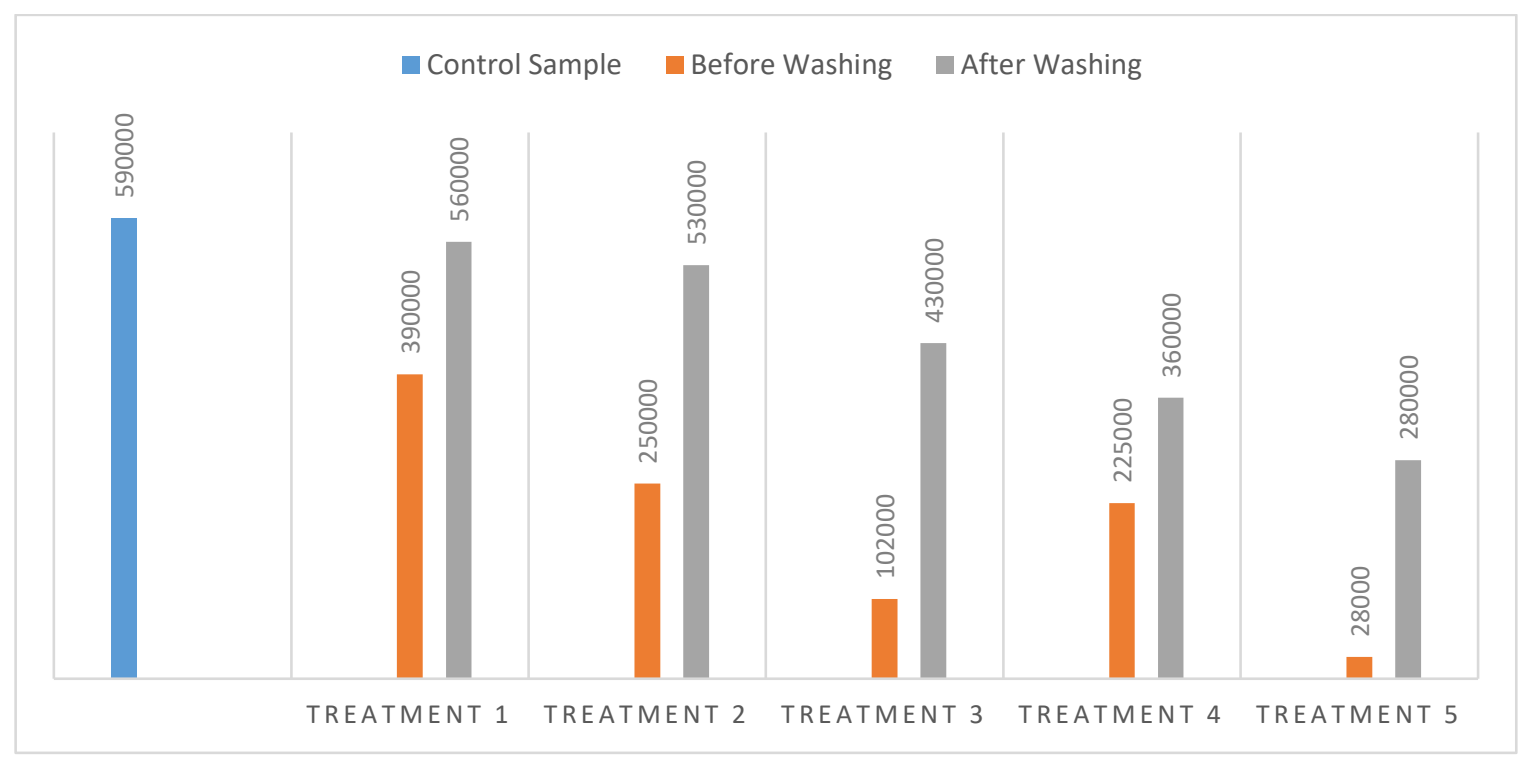

Figure 2. The antibacterial activity results of the treated fabrics against E. coli

According to the antibacterial test results, in the unwashed samples, the most effective samples were the samples treated by cyclodextrin derivative (sulfated $\beta-C D$ ), while in the washed samples, the most effective samples were the samples treated by crosslinking agent (EDTA). Considering these results, it was understood that S- $\beta$-CD showed better antibacterial activity than $\beta-C D$ via sulfur-oxygen bonds and EDTA crosslinking agent ensured that the inclusion complexes remained attached to the fabric surface even after washing. This fact was attributed to the improved crosslinking between hydroxyl groups of cotton and inclusion complexes thanks to EDTA. In terms of microorganism type, the antibacterial activity against gram positive bacteria ( $S$. aureus) was seen to be better than gram negative bacteria $(E$. coli). This result was attributed to the fact that gram positive bacteria have one cytoplasmic cell membrane however gram negative bacteria have two cell membranes (cytoplasmic membrane and outer membrane) as reported in the related studies (Nogueira 2018; Ogunsona et al. 2020). El-Rafie et al. 2010; Hebeish et al. 2014b; Ru et al. 2018 and Sharma et al. 2018 also reported the antibacterial activity of nanosilver-based antibacterial textiles was better against $S$. aureus than E. coli as similar to the results of this study. 
In the first part of the study, the washing process was carried out at $60^{\circ} \mathrm{C}$. But in the second part of the study, the milder and widely used household type temperature $\left(40^{\circ} \mathrm{C}\right)$ was preferred as washing condition for repeated washings. The repeated washing cycles $(1,5$ and 10$)$ were applied to the sample treated by AgNPs, sulfated $\beta-\mathrm{CD}$ and EDTA in other words treatment 5.

The antibacterial activity test results of the sample treated by AgNPs, sulfated $\beta$-CD and EDTA against $S$. aureus

and against $E$. coli before washing and after 1,5 and 10 washing cycles at $40^{\circ} \mathrm{C}$ are shown in Table 6 and 7 respectively.

Table 6. The antibacterial activity of the sample treated by treatment 5 before and after repeated washing at $40^{\circ} \mathrm{C}$ against $S$. aureus

\begin{tabular}{|c|c|c|c|}
\hline $\begin{array}{c}\text { Treatment } 5 \\
(\text { S- } \beta-C D+\text { AgNPs + EDTA })\end{array}$ & $\begin{array}{c}\text { Bacterial count for } \\
\text { control sample after } \\
24 \mathrm{~h}\end{array}$ & $\begin{array}{c}\text { Bacterial count for } \\
\text { treated sample after } \\
\mathbf{2 4 h}\end{array}$ & $\begin{array}{l}\text { Bacterial } \\
\text { reduction } \\
(\%)\end{array}$ \\
\hline Before washing & 360.000 & 18.000 & 95.00 \\
\hline After 1 washing at $40^{\circ} \mathrm{C}$ & 360.000 & 42.000 & 88.33 \\
\hline After 5 washing at $40{ }^{\circ} \mathrm{C}$ & 360.000 & 58.000 & 83.88 \\
\hline After 10 washing at $40^{\circ} \mathrm{C}$ & 360.000 & 74.000 & 79.44 \\
\hline
\end{tabular}

Table 7. The antibacterial activity of the sample treated by treatment 5 before and after repeated washing at $40^{\circ} \mathrm{C}$ against $E$. coli

\begin{tabular}{l|c|c|c}
\hline $\begin{array}{c}\text { Treatment 5 } \\
(\mathbf{S - \beta}-\mathbf{C D}+\mathbf{A g N P s}+\mathbf{E D T A})\end{array}$ & $\begin{array}{c}\text { Bacterial count for } \\
\text { control sample after } \\
\mathbf{2 4 h}\end{array}$ & $\begin{array}{c}\text { Bacterial count for } \\
\text { treated sample after } \\
\mathbf{2 4 h}\end{array}$ & $\begin{array}{c}\text { Bacterial } \\
\text { reduction } \\
(\boldsymbol{\%})\end{array}$ \\
\hline Before washing & 375.000 & 18.000 & 95.25 \\
\hline After 1 washing at 40 ${ }^{\circ} \mathbf{C}$ & 375.000 & 58.000 & 84.53 \\
\hline After 5 washing at 40 ${ }^{\circ} \mathbf{C}$ & 375.000 & 68.000 & 81.87 \\
\hline After 10 washing at 40 ${ }^{\circ} \mathbf{C}$ & 375.000 & 85.000 & 77.33 \\
\hline
\end{tabular}

According to the results, it was seen that the sample treated by AgNPs, sulfated $\beta$-CD and EDTA could maintain

\section{Physical tests}

\section{Add-on results}

274 The add-on results are given in Table 8.

Table 8. Add-on results

\begin{tabular}{l|c|c}
\hline \multicolumn{1}{c|}{ Treatment } & Approx. weight of the sample (g) & Add-on (\%) \\
\hline Untreated & 0.917 & - \\
\hline $\begin{array}{l}\text { Treatment 1 } \\
\text { AgNPs }\end{array}$ & 0.925 & 0.80 \\
\hline $\begin{array}{l}\text { Treatment 2 } \\
\beta \text {-cyclodextrin + AgNPs }\end{array}$ & 0.935 & 1.96 \\
\hline $\begin{array}{l}\text { Treatment 3 } \\
\text { S- } \beta \text {-cyclodextrin + AgNPs }\end{array}$ & 0.937 & 2.18 \\
\hline $\begin{array}{l}\text { Treatment 4 } \\
\beta \text {-cyclodextrin + AgNPs + EDTA }\end{array}$ & 0.940 & 2.50 \\
\hline $\begin{array}{l}\text { Treatment 5 } \\
\text { S- } \beta \text {-cyclodextrin + AgNPs + EDTA }\end{array}$ & 0.951 & 3.70 \\
\hline
\end{tabular}


The add-on percentage values of the samples were found to be between $0.8 \%$ and $3.7 \%$ and this difference was attributed to the variation in the inclusion complex formation on the cotton surface. So, since the values of the treatment 4 and 5 were higher than the others, it can be said that the crosslinking agent (EDTA) enabled more stable inclusion complex formation. On the other hand, since the value of the treatment 1 was the lowest, it can be attributed to the absence of the inclusion complex on the cotton surface.

\section{Tensile strength results}

The tensile strength and elongation at break values in the weft and warp direction of fabrics treated with $\beta$ cyclodextrin, sulfated $\beta$-cyclodextrin, EDTA and silver nanoparticles and untreated fabrics are given in Table 9.

Table 9. Tensile strength and elongation at break results

\begin{tabular}{l|c|c|c|c|c|c}
\hline \multirow{2}{*}{ Treatment } & \multicolumn{2}{|c|}{ Elongation at break } & \multicolumn{2}{c}{ Tensile strength } & \multicolumn{2}{c}{ Tensile strength increase } \\
\cline { 2 - 7 } & Weft (\%) & Warp (\%) & Weft (N) & Warp (N) & Weft (\%) & Warp (\%) \\
\hline Untreated & 23.35 & 19.14 & 591 & 1014 & - & - \\
\hline $\begin{array}{l}\text { Treatment 1 } \\
\text { AgNPs }\end{array}$ & 15.77 & 15.94 & 625 & 1035 & 5.54 & 2.03 \\
\hline $\begin{array}{l}\text { Treatment 2 } \\
\beta \text {-cyclodextrin + AgNPs }\end{array}$ & 14.67 & 14.97 & 725 & 1126 & 18.56 & 9.97 \\
\hline $\begin{array}{l}\text { Treatment 3 } \\
\text { S- } \beta \text {-cyclodextrin + AgNPs }\end{array}$ & 15.03 & 15.47 & 720 & 1112 & 17.93 & 8.84 \\
\hline $\begin{array}{l}\text { Treatment 4 } \\
\beta \text {-cyclodextrin + AgNPs + EDTA }\end{array}$ & 14.26 & 14.40 & 735 & 1159 & 19.67 & 12.51 \\
\hline $\begin{array}{l}\text { Treatment 5 } \\
\text { S- } \beta \text {-cyclodextrin + AgNPs + EDTA }\end{array}$ & 14.76 & 15.30 & 728 & 1144 & 18.86 & 11.33 \\
\hline
\end{tabular}

It was observed that the finishing treatments increased the tensile strength values of the fabrics. The tensile strength of the cotton fabric significantly increased in fabrics treated by $\beta-C D$ and S- $\beta-C D$ in comparison to the fabric treated by AgNPs alone. The increase in the strength of cotton fabric with $\beta-\mathrm{CD}$ and S- $\beta-\mathrm{CD}$ can be explained by the plasticizing effect of cyclodextrins on the cotton fiber structure. By disrupting the intermolecular and/or intramolecular $\mathrm{H}$ bond between cellulose chains, $\beta-\mathrm{CD} / \mathrm{S}-\beta-\mathrm{CD}$ decreased the restricted movement of cellulose chains and thus increased the tensile strength of the cotton samples as reported in the related study of Setthayanond et al. 2017. EDTA supported the increase in tensile strength positively as well. On the other hand, a slight increase in the tensile strength was also observed in the cotton sample treated by AgNPs alone. Therefore, it was thought that nanosilver application was also effective in mechanical properties of the cotton samples. Taking the related studies into consideration, it was understood that the improved mechanical properties could be attributed to the binding of AgNPs onto the hydroxyl groups of the cellulose chains of the cotton fibers (Ravindra et al. 2010; Ibrahim and Hassan 2016). When the elongation at break values were examined, it was observed that the elongation at break values of the treated fabrics were lower than the values of the untreated fabric. This was attributed to the increase in tensile strength and the decrease in the elongation at break values was found to be in line with the increase in tensile strength values.

\section{Bending length and bending rigidity results}

302 The bending length and bending rigidity values of the samples are given in Table 10. 
Table 10. Bending length and bending rigidity results

\begin{tabular}{|c|c|c|c|c|c|}
\hline \multirow[b]{2}{*}{ Treatment } & \multicolumn{2}{|c|}{ Weft } & \multicolumn{2}{|c|}{ Warp } & \multirow{2}{*}{$\begin{array}{l}\text { General } \\
\text { bending } \\
\text { rigidity } \\
\text { (mg.cm) }\end{array}$} \\
\hline & $\begin{array}{l}\text { Bending } \\
\text { length } \\
\text { (cm) }\end{array}$ & $\begin{array}{c}\text { Bending } \\
\text { rigidity } \\
\text { (mg.cm) }\end{array}$ & $\begin{array}{c}\text { Bending } \\
\text { length } \\
\text { (cm) }\end{array}$ & $\begin{array}{l}\text { Bending } \\
\text { rigidity } \\
\text { (mg.cm) }\end{array}$ & \\
\hline Untreated & 1.66 & 112.01 & 2.18 & 253.82 & 168.62 \\
\hline $\begin{array}{l}\text { Treatment } 1 \\
\text { AgNPs }\end{array}$ & 1.72 & 124.66 & 2.20 & 260.87 & 180.34 \\
\hline $\begin{array}{l}\text { Treatment } 2 \\
\beta \text {-cyclodextrin }+ \text { AgNPs }\end{array}$ & 1.81 & 145.28 & 2.31 & 302.00 & 209.46 \\
\hline $\begin{array}{l}\text { Treatment } 3 \\
\text { S- } \beta \text {-cyclodextrin + AgNPs }\end{array}$ & 1.86 & 157.65 & 2.38 & 330.30 & 228.20 \\
\hline $\begin{array}{l}\text { Treatment } 4 \\
\beta \text {-cyclodextrin + AgNPs + EDTA }\end{array}$ & 1.90 & 168.05 & 2.46 & 364.73 & 247.57 \\
\hline $\begin{array}{l}\text { Treatment } 5 \\
S-\beta \text {-cyclodextrin + AgNPs + EDTA }\end{array}$ & 1.93 & 176.13 & 2.52 & 392.07 & 262.80 \\
\hline
\end{tabular}

After the finishing treatments, the bending length and bending rigidity of the fabrics increased. This fact showed that the finishing processes caused stiffness in the fabric handle. In terms of the application of $\beta$-CD or sulfated $\beta$ $\mathrm{CD}$, it was found that sulfated $\beta-\mathrm{CD}$ caused more stiffness and EDTA leaded the stiffness to increase. However, there was no significant difference between the untreated fabric and the fabric to which AgNPs alone were applied. This fact was attributed to the variation in the inclusion complex formation on the cotton surface as in the add-on results.

\section{Stiffness results}

In order to verify the bending length and bending rigidity results by another test method, stiffness values of the samples were also measured by pneumatic stiffness tester. Stiffness values of the samples are given in Table 11.

Table 11. Stiffness results

\begin{tabular}{l|c|c}
\hline \multicolumn{1}{c|}{ Treatment } & Stiffness $(\mathbf{c N})$ & Stiffness increase (\%) \\
\hline Untreated & 352.25 & - \\
\hline $\begin{array}{l}\text { Treatment 1 } \\
\text { AgNPs }\end{array}$ & 356.00 & 1.06 \\
\hline $\begin{array}{l}\text { Treatment 2 } \\
\beta \text {-cyclodextrin + AgNPs }\end{array}$ & 431.00 & 22.35 \\
\hline $\begin{array}{l}\text { Treatment 3 } \\
\text { S- } \beta \text {-cyclodextrin + AgNPs }\end{array}$ & 434.25 & 23.27 \\
\hline $\begin{array}{l}\text { Treatment 4 } \\
\beta \text {-cyclodextrin + AgNPs + EDTA }\end{array}$ & 438.00 & 24.34 \\
\hline $\begin{array}{l}\text { Treatment 5 } \\
\text { S- } \beta \text {-cyclodextrin + AgNPs + EDTA }\end{array}$ & 441.25 & 25.26 \\
\hline
\end{tabular}

The stiffness values were found to be in accordance with add-on and bending rigidity results, namely the more inclusion complex formation gave rise to more stiffness. Similarly, stiffer handle in comparison to untreated cotton after MCT- $\beta$-cyclodextrin treatment was reported by Setthayanond et al. 2017. 
325 Thickness values of the samples are given in Table 12.

Table 12. Thickness results

\begin{tabular}{l|c|c}
\hline \multicolumn{1}{c|}{ Treatment } & Thickness (mm) & Thickness increase (\%) \\
\hline Untreated & 0.440 & - \\
\hline $\begin{array}{l}\text { Treatment } \mathbf{1} \\
\text { AgNPs }\end{array}$ & 0.490 & 11.36 \\
\hline $\begin{array}{l}\text { Treatment 2 } \\
\beta \text {-cyclodextrin + AgNPs }\end{array}$ & 0.500 & 13.63 \\
\hline $\begin{array}{l}\text { Treatment 3 } \\
\text { S- } \beta \text {-cyclodextrin + AgNPs }\end{array}$ & 0.510 & 15.90 \\
\hline $\begin{array}{l}\text { Treatment 4 } \\
\beta \text {-cyclodextrin + AgNPs + EDTA }\end{array}$ & 0.520 & 18.18 \\
\hline $\begin{array}{l}\text { Treatment 5 } \\
\text { S- } \beta \text {-cyclodextrin + AgNPs + EDTA }\end{array}$ & 0.525 & 19.31 \\
\hline
\end{tabular}

After the finishing processes, an increase in thickness was seen in the treated fabrics compared to the untreated fabric. It was observed that the fabric sample treated by S- $\beta$-CD+AgNPs+EDTA had higher thickness value compared to other samples similarly to the other physical test results depending on the same reasons.

\section{Whiteness and yellowness index results}

332 The whiteness and yellowness index values are given in Table 13.

Table 13. Whiteness and yellowness index results

\begin{tabular}{l|c|c}
\hline \multicolumn{1}{c|}{ Treatment } & $\begin{array}{c}\text { Whiteness index } \\
\text { (Stensby) }\end{array}$ & $\begin{array}{c}\text { Yellowness index } \\
\text { (E 313) }\end{array}$ \\
\hline Untreated & 86.09 & 4.59 \\
\hline $\begin{array}{l}\text { Treatment 1 } \\
\text { AgNPs }\end{array}$ & 85.50 & 5.19 \\
\hline $\begin{array}{l}\text { Treatment 2 } \\
\beta \text {-cyclodextrin + AgNPs }\end{array}$ & 84.91 & 5.15 \\
\hline $\begin{array}{l}\text { Treatment 3 } \\
\text { S- } \beta \text {-cyclodextrin + AgNPs }\end{array}$ & 76.69 & 8.86 \\
\hline $\begin{array}{l}\text { Treatment 4 } \\
\beta \text {-cyclodextrin + AgNPs + EDTA }\end{array}$ & 83.54 & 5.36 \\
\hline $\begin{array}{l}\text { Treatment 5 } \\
\text { S- } \beta \text {-cyclodextrin + AgNPs + EDTA }\end{array}$ & 75.13 & 9.75 \\
\hline
\end{tabular}

After the finishing treatments, it was observed that the degree of whiteness decreased in all samples compared to the untreated sample. On the other hand, the degree of yellowness of all samples increased significantly especially in the samples treated by sulfated $\beta$-cyclodextrin compared to the untreated sample. This color change in the samples treated by sulfated $\beta$-cyclodextrin can be explained by the combined effect of nanosilver application, sulfation reactions of the cyclodextrin and the curing conditions. The color change (from colorless to cream yellow or to brownish yellow) of the cotton fabrics after nanosilver application was also reported by other studies (ElShishtawy et al. 2011; Montazer et al. 2012; Bozaci et al. 2015; Ibrahim and Hassan 2016; Ru et al. 2018). When these studies were considered, it can be said that the color change results of this study were in acceptable limits since the final color of the sample whose color change was maximum was cream yellow. 
The spectra of $\beta$-cyclodextrin powder and sulfated $\beta$-cyclodextrin powder are given in Figure 3.

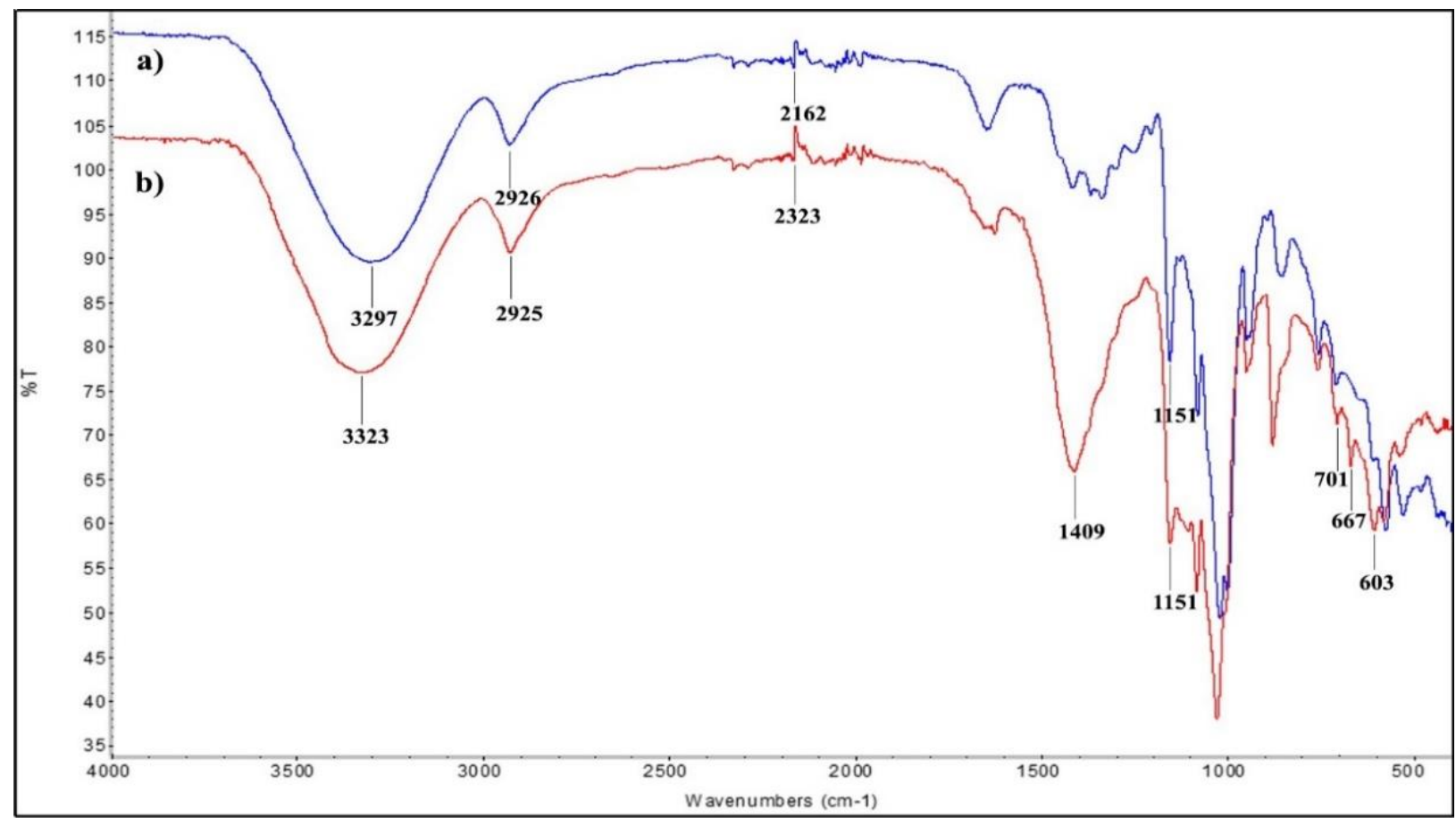

Figure 3. FT-IR spectra of $\beta-C D$ and S- $\beta-C D$ powders a) $\beta-C D$ powder, b) S- $\beta-C D$ powder

According to the FTIR spectra, the main groups were the same both for $\beta$-CD and S- $\beta$-CD powders. These bonds were absorption bands at 3323 and $3297 \mathrm{~cm}^{-1}$ (-OH bonds), the bands at 2926, 2925, 2323 and $2162 \mathrm{~cm}^{-1}(\mathrm{C}-\mathrm{H}$ and $\mathrm{CH}_{2}$ aliphatic bonds) and the bands at $1151 \mathrm{~cm}^{-1}$ (C-O-C bonds). However, only the changes caused by S-O (sulfur-oxygen) bond were observed on the sulfated $\beta$-cyclodextrin powder in $1409 \mathrm{~cm}^{-1}$ and between the values of $701 \mathrm{~cm}^{-1}$ and $603 \mathrm{~cm}^{-1}$. These results confirmed the related studies (Yang 2009; Abdel-Halim et al. 2011; Selvam et al. 2012; Andrade et al. 2014) and also revealed the difference between the chemical structures of $\beta$-cyclodextrin and sulfated $\beta$-cyclodextrin.

\section{Scanning electron microscopy (SEM) analysis results}

SEM images of the treated samples and untreated sample are given in Figure 4. 


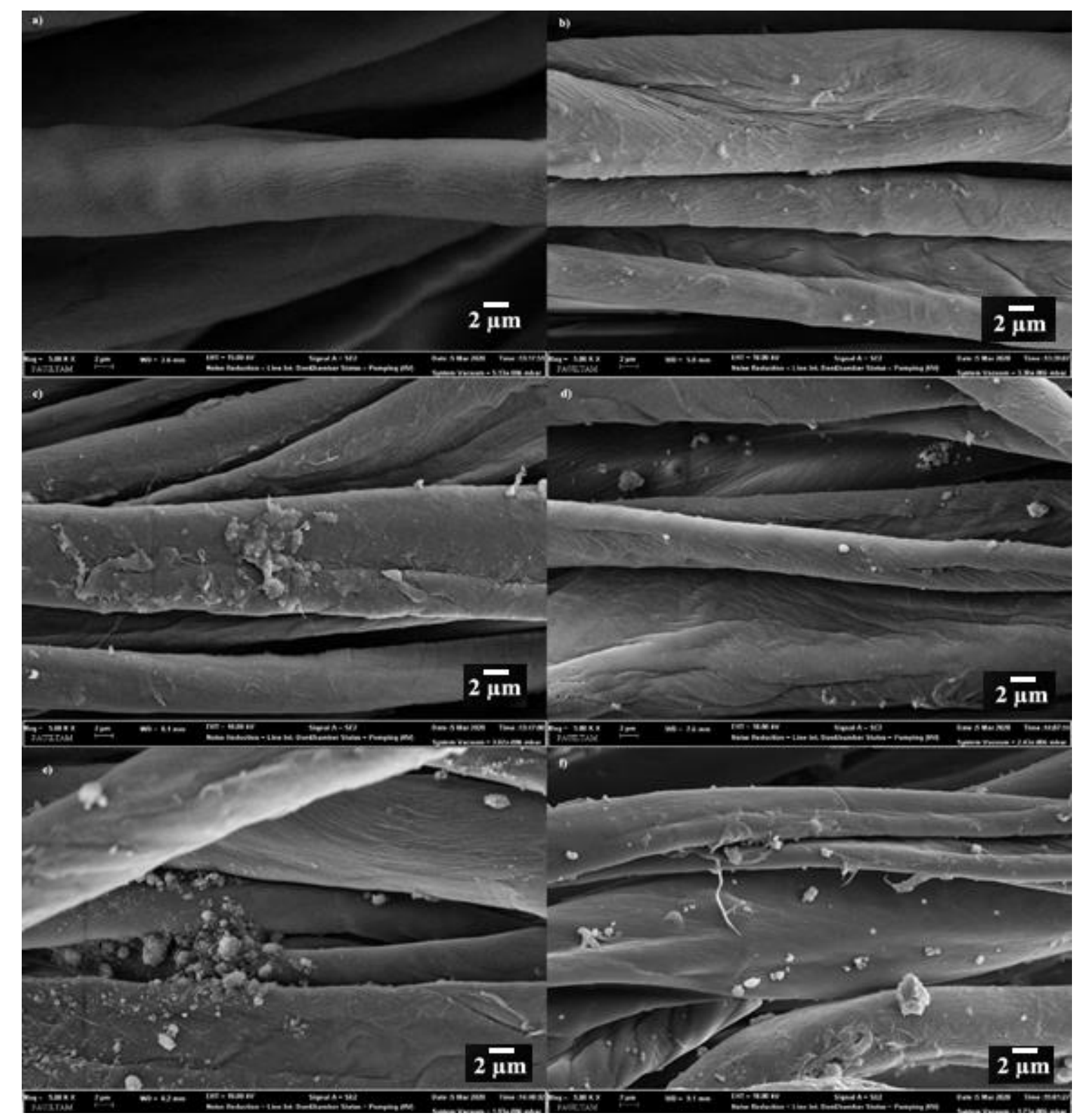

Figure 4. SEM images of the samples a) Untreated sample, b) sample treated by treatment 1 (AgNPs) c) sample treated by treatment $2(\beta-\mathrm{CD}+\mathrm{AgNPs}) \mathrm{d})$ sample treated by treatment $3(\mathrm{~S}-\beta-\mathrm{CD}+\mathrm{AgNPs}) \mathrm{e})$ sample treated by treatment $4(\beta-\mathrm{CD}+\mathrm{AgNPs}+\mathrm{EDTA}) \mathrm{f})$ sample treated by treatment $5(\mathrm{~S}-\beta-\mathrm{CD}+\mathrm{AgNPs}+\mathrm{EDTA})$

According to the SEM images, the surface of the untreated cotton sample (Fig. 4a) was smooth and clear as expected while the other surfaces included the residues of the silver nanoparticles. When the SEM image of the sample treated by silver nanoparticles (AgNPs) alone was examined (Fig. 4b), it was found that silver nanoparticles were less adhered to the surface of the samples than the samples treated by $\beta$-cyclodextrin and its derivative. When the sample surfaces treated by $\beta$-cyclodextrin and silver nanoparticles (AgNPs) (Fig. 4c) were examined, it was observed that silver nanoparticles did not show uniform distribution and formed aggregates in certain areas. When the sample surfaces treated by sulfated $\beta$-cyclodextrin and silver nanoparticles (AgNPs) were examined (Fig. 4d), it was observed that silver nanoparticles showed a uniform distribution and the quantity of the inclusion complexes formed on the surface increased. Moreover, the application of EDTA crosslinking agent also ensured a strong adhesion of inclusion complexes to surfaces and supported the increase in the quantity of the inclusion complexes (Fig. $4 \mathrm{e}$ and $4 \mathrm{f}$ ). 
By the EDX analysis, the atomic percentage of the silver nanoparticles (AgNPs) were determined. As mentioned in the methods part, the samples were coated with a thin gold/palladium film layer to increase the conductivity during SEM and EDX analysis. Therefore, in order to calculate the accurate atomic percentages of the elements, the atomic percentages of gold and palladium elements related to the coating in the analysis were eliminated and were remained as unidentified peaks in the images in Fig. 5. The atomic percentage of the silver nanoparticles in the treated samples and in the untreated sample are given in Table 14 and related spectra of the samples are shown in Fig. 5.

Table 14. Atomic percentage of silver nanoparticles in the samples

\begin{tabular}{l|c}
\multicolumn{1}{c|}{ Treatment } & $\begin{array}{c}\text { Silver nanoparticles (AgNPs) } \\
\text { (Atomic \%) }\end{array}$ \\
\hline Untreated Sample & - \\
\hline Treatment 1 (AgNPs) & 0.38 \\
\hline Treatment 2 ( $\beta-C D+$ AgNPs) & 0.63 \\
\hline Treatment 3 (S- $\beta$-CD + AgNPs) & 4.42 \\
\hline Treatment 4 ( $\beta-C D+$ AgNPs + EDTA) & 1.01 \\
\hline Treatment 5 (S- $\beta-C D+$ AgNPs + EDTA) & 8.67 \\
\hline
\end{tabular}
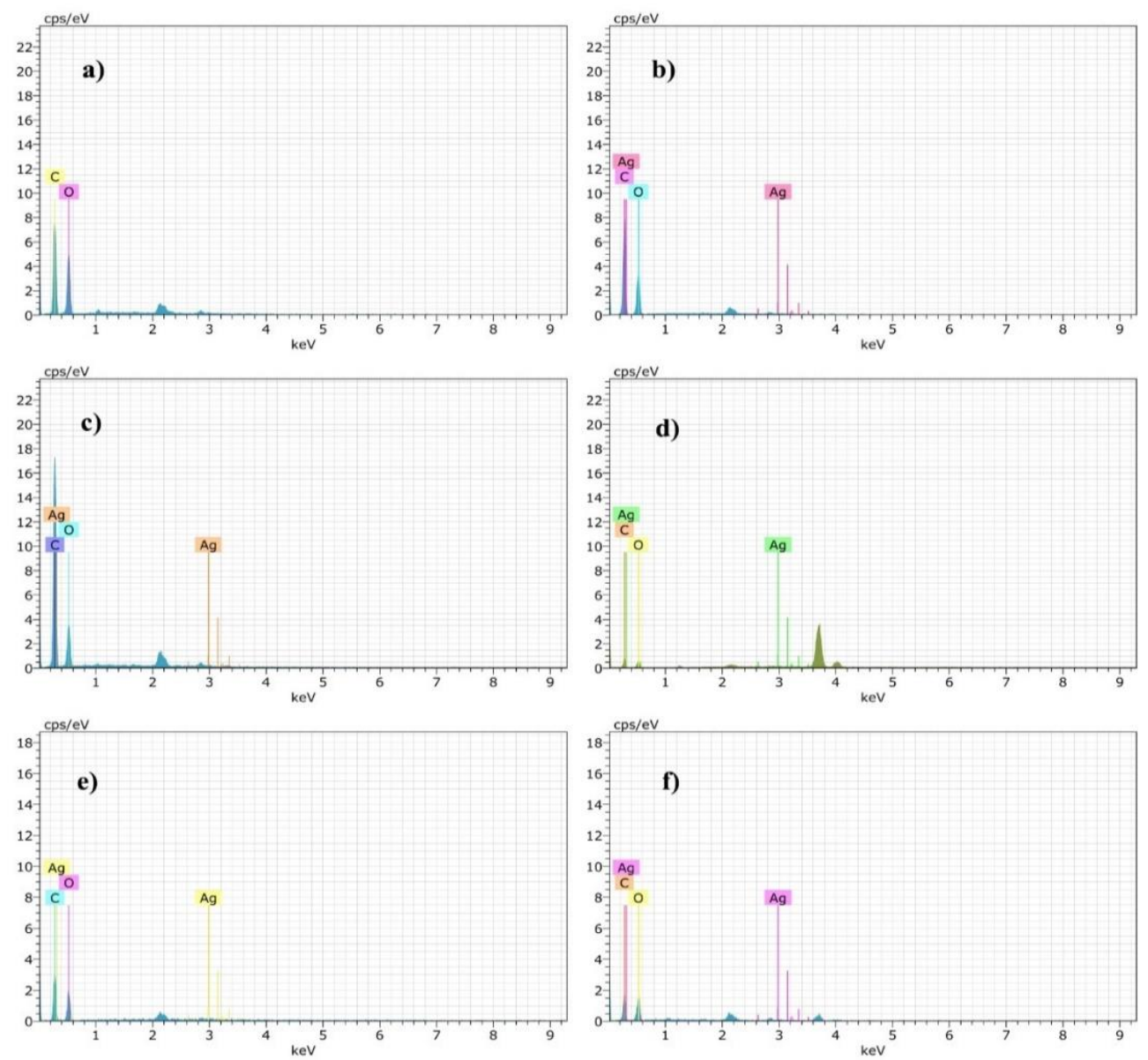

Figure 5. EDX spectra of the samples a) Untreated sample, b) sample treated by treatment 1 (AgNPs) c) sample treated by treatment $2(\beta-\mathrm{CD}+\mathrm{AgNPs}) \mathrm{d})$ sample treated by treatment $3(\mathrm{~S}-\beta-\mathrm{CD}+\mathrm{AgNPs})$ e) sample treated by treatment $4(\beta-\mathrm{CD}+\mathrm{AgNPs}+\mathrm{EDTA}) \mathrm{f})$ sample treated by treatment $5(\mathrm{~S}-\beta-\mathrm{CD}+\mathrm{AgNPs}+\mathrm{EDTA})$ 
According to these results, it was seen that the amount of silver nanoparticles in the fabric sample treated by sulfated $\beta$-cyclodextrin was much higher than the fabric sample treated by $\beta$-cyclodextrin. It was also observed that the samples treated by EDTA crosslinking agent possessed higher Ag amount than the others, and thus, it was observed that EDTA binded more silver nanoparticles (AgNPs) and inclusion complexes on the surface. It was concluded that the sample with the highest quantity of silver nanoparticles was the sample treated by treatment 5 , in other words by $S-\beta-C D+A g N P s+$ EDTA.

\section{$X$-ray diffraction (XRD) analysis results}

XRD spectra of the silver nanoparticles are given in Figure 6.

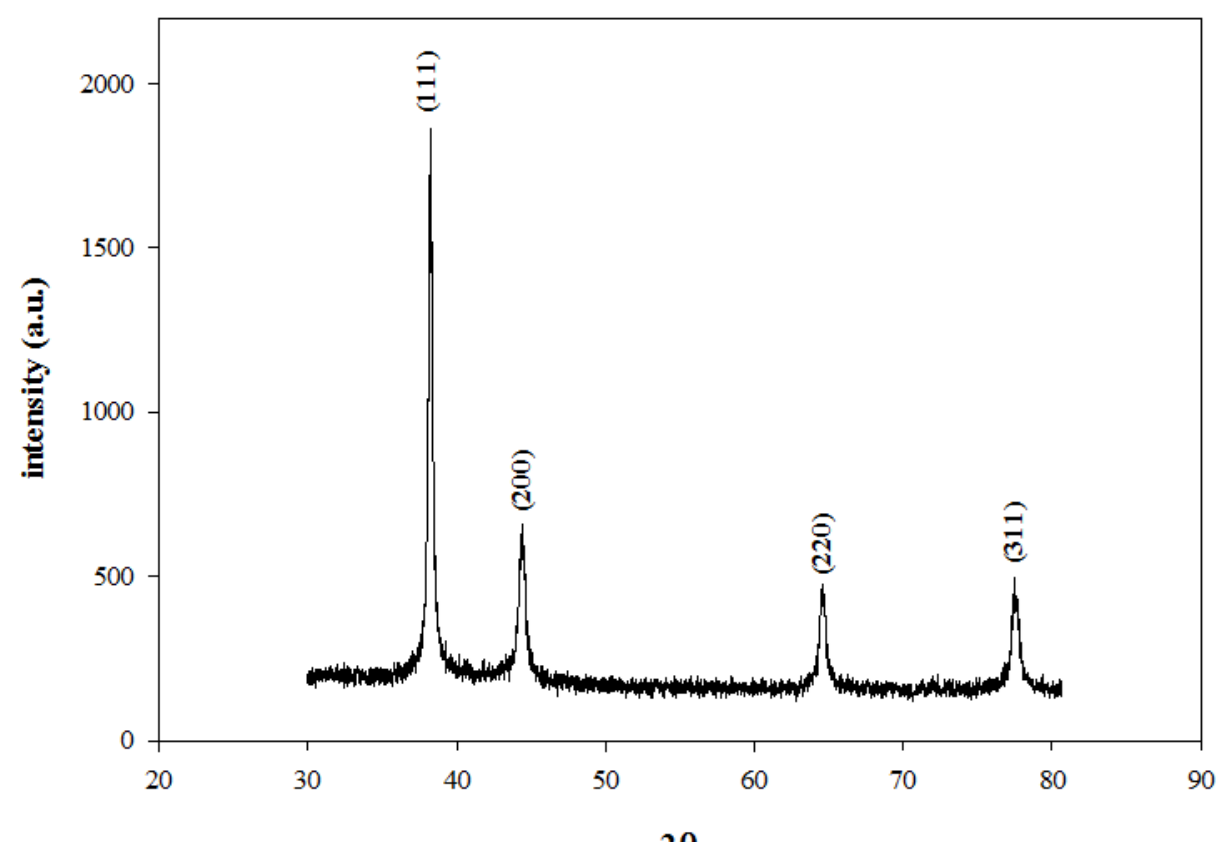

Figure 6. XRD spectra of the silver nanoparticles

XRD analysis was used to characterize the crystalline nature of the silver nanoparticles. Silver nanoparticles showed diffraction peaks at $2 \theta$ in the planes of (111), (200), (220) and (311) respectively. These planes were characteristics of the face-centered cubic silver crystals. The planes were indexed with lattice constants $a=4.077$ $\AA$ and matched to the ICDD (International Centre for Diffraction Data) card no. 01-087-0720. In addition, similar Bragg's reflections confirmed the silver nanoparticles as reported in the related studies (Andrade et al. 2014; Ru et al. 2018; Sharma et al. 2018; Eid et al. 2020; Salem et al. 2020). Then, the mean particle size (D) of the silver nanoparticles was calculated with Debye-Scherrer equation and found as $31 \mathrm{~nm}$.

\section{Conclusion}

In this study, the effects of $\beta$-cyclodextrin ( $\beta$-CD) complex and derivative (S- $\beta$-CD) complex with silver nanoparticles on cotton fabric were investigated and compared. Five treatments were applied as AgNPs alone; $\beta$ CD + AgNPs; S- $\beta-C D+$ AgNPs; $\beta-C D+$ AgNPs + EDTA and S- $\beta-C D+$ AgNPs + EDTA to cotton samples. Antibacterial test results showed that the most effective treatment was S- $\beta-C D+$ AgNPs + EDTA and this treatment could be stable to 10 washing cycles as $79 \%$ against $S$. aureus bacteria and $77 \%$ against $E$. coli bacteria. Physical test results showed that the treatments caused an increase in weight, thickness, stiffness, tensile strength and yellowness values of the samples. In the samples treated by S- $\beta-C D$, relatively more changes were obtained in the physical properties than the samples treated by $\beta$-CD. FTIR analysis verified the difference in the chemical 
structure of the $\beta-C D$ and $S-\beta-C D$ due to the S-O (sulfur-oxygen) bond. SEM analysis verified the inclusion complexes between AgNPs and $\beta-C D$ or S- $\beta-C D$ on the cotton surface and the fact that EDTA supported the increase in the quantity of the inclusion complexes. EDX analysis detected the atomic percentage of silver nanoparticles on the samples and determined the highest quantity of silver nanoparticles was in the sample treated by $S-\beta-C D+A g N P s+$ EDTA. XRD analysis confirmed the silver nanoparticles were in the cubic structure and in the average particle size of $31 \mathrm{~nm}$.

Author contribution The authors conducted the research and reviewed the manuscript together.

Funding The authors did not receive funding.

Availability of data and material The data are available from the corresponding author.

Code availability Not applicable.

\section{Declarations}

Conflict of interest The authors declare that they have no conflict of interest.

Ethical approval This study does not involve any animal and human sample.

\section{References}

Abdel-Halim ES, Abdel-Mohdy FA, Fouda MMG, El-Sawy SM, Hamdy IA, Al-Deyab SS (2011) Antimicrobial activity of monochlorotriazinyl- $\beta$-cyclodextrin/chlorohexidin diacetate finished cotton fabrics. Carbohydr Polym 86(3):1389-1394

Ammayappan L, Moses JJ (2009) An overview on application of cyclodextrins in textile product enhancement. J Text Assoc 70(1):9-18

Andrade PF, de Faria AF, da Silva DS, Bonacin JA, do Carmo Goncalves M (2014) Structural and morphological investigations of $\beta$-cyclodextrin-coated silver nanoparticles. Colloids Surf B:Biointerfaces 118:289-297

Arik B (2021) Common and nano-antimicrobial textile finishes. In: Mondal MIH (ed) Antimicrobial textiles from natural resources, Chap. 3. Woodhead Publishing, pp 87-117

Arslan M (2012) Synthesis and extraction properties of magnetic $\beta$-cyclodextrin nanoparticles towards some chiral carboxylic acids. Master thesis, Selcuk University, Turkey

Aubert-Viard F, Mogrovejo-Valdivia A, Tabary N, Maton M, Chai F, Neut C, Martel B, Blanchemain N (2019) Evaluation of antibacterial textile covered by layer-by-layer coating and loaded with chlorhexidine for wound dressing application. Mater Sci Eng C 100:554-563

Bhaskara-Amrit UR, Agrawal PB, Warmoeskerken MMCG (2011) Applications of $\beta$-cyclodextrins in textiles. Autex Res J 11(4):94-101

Bozaci E, Akar E, Ozdogan E, Demir A, Altinisik A, Seki Y (2015) Application of carboxymethylcellulose hydrogel based silver nanocomposites on cotton fabrics for antibacterial property. Carbohydr Polym 134:128-135

Butola BS, Mohammad F (2016) Silver nanomaterials as future colorants and potential antimicrobial agents for natural and synthetic textile materials. RSC Adv 6(50):44232-44247

Carneiro SB, Costa Duarte FÍ, Heimfarth L, Siqueira Quintans JDS, Quintans-Júnior LJ, Veiga Júnior VFD, Neves de Lima ÁA (2019) Cyclodextrin-drug inclusion complexes: In vivo and in vitro approaches. Int J Mol Sci 20(3):642 
Eid AM, Fouda A, Niedbała G, Hassan SED, Salem SS, Abdo AM, Hetta HF, Shaheen TI (2020) Endophytic Streptomyces laurentii mediated green synthesis of Ag-NPs with antibacterial and anticancer properties for developing functional textile fabric properties. Antibiotics 9(10):641

El-Rafie MH, Mohamed AA, Shaheen TI, Hebeish A (2010) Antimicrobial effect of silver nanoparticles produced by fungal process on cotton fabrics. Carbohydr Polym 80:779-782

El-Shishtawy RM, Asiri AM, Abdelwahed NA, Al-Otaibi MM (2011) In situ production of silver nanoparticle on cotton fabric and its antimicrobial evaluation. Cellulose 18(1):75-82

Gao Y, Cranston R (2008) Recent advances in antimicrobial treatments of textiles. Text Res J 78(1):60-72

George C, Kuriakose S, Prakashkumar B, Mathew T (2010) Synthesis, characterisation and antibacterial applications of water-soluble, silver nanoparticle encapsulated $\beta$-cyclodextrin. Supramol Chem 22(9):511-516

Grigoriu AM, Luca C, Grigoriu A (2008) Cyclodextrin applications in the textile industry. Cellul Chem Technol 42(1-3):103-112

Hebeish A, El-Shafei A, Sharaf S, Zaghloul S (2014a) In situ formation of silver nanoparticles for multifunctional cotton containing cyclodextrin. Carbohydr Polym 103:442-447

Hebeish A, El-Shafei A, Sharaf S, Zaghloul S (2014b) Development of improved nanosilver-based antibacterial textiles via synthesis of versatile chemically modified cotton fabric. Carbohydr Polym 113:455-462

Ibrahim HM, Hassan MS (2016) Characterization and antimicrobial properties of cotton fabric loaded with green synthesized silver nanoparticles. Carbohydr Polym 151:841-850

Jaiswal S, Duffy B, Jaiswal AK, Stobie N, McHale P (2010) Enhancement of the antibacterial properties of silver nanoparticles using $\beta$-cyclodextrin as a capping agent. Int J Antimicrob Agents 36(3):280-283

Malini S, Kumar SV, Hariharan R, Bharathi AP, Devi PR, Hemananthan E (2020) Antibacterial, photocatalytic and biosorption activity of chitosan nanocapsules embedded with Prosopis juliflora leaf extract synthesized silver nanoparticles. Mater Today: Proc 21:828-832

Montazer M, Alimohammadi F, Shamei A, Rahimi MK (2012) In situ synthesis of nano silver on cotton using Tollens' reagent. Carbohydr Polym 87(2):1706-1712

Nogueira FÁS (2018) Covalent and non-covalent strategies for surface modification of different textile materials with antimicrobial properties. PhD thesis, Universidade da Beira Interior, Portugal

483 Popescu O, Dunca S, Grigoriu A (2013) Antibacterial action of silver applied on cellulose fibers grafted with

Ogunsona EO, Muthuraj R, Ojogbo E, Valerio O, Mekonnen TH (2020) Engineered nanomaterials for antimicrobial applications: a review. Appl Mater Today 18:100473

487 Radu CD, Parteni O, Ochiuz L (2016) Applications of cyclodextrins in medical textiles. J Control Release 224: $488 \quad 146-157$

489 Rai M, Yadav A, Gade A (2009) Silver nanoparticles as a new generation of antimicrobials. Biotechnol Adv 27(1): 
Ravindra S, Mohan YM, Reddy NN, Raju KM (2010) Fabrication of antibacterial cotton fibres loaded with silver nanoparticles via green approach. Colloids Surf A: Physicochem Eng Asp 367:31-40

493 Řezanka M (2018) Synthesis of cyclodextrin derivatives. In: Fourmentin S, Crini G, Lichtfouse E (eds) 494 Cyclodextrin fundamentals, reactivity and analysis, Environmental chemistry for a sustainable world, Vol. 16. 495 Springer, Cham, pp 57-103

496 Ru J, Qian X, Wang Y (2018) Study on antibacterial finishing of cotton fabric with silver nanoparticles stabilized 497 by nanoliposomes. Cellulose 25(9):5443-5454

498 Salem SS, El-Belely EF, Niedbała G, Alnoman MM, Hassan SED, Eid AM, Shaheen TI, Elkelish A, Fouda A 499 (2020) Bactericidal and in-vitro cytotoxic efficacy of silver nanoparticles (Ag-NPs) fabricated by endophytic 500 actinomycetes and their use as coating for the textile fabrics. Nanomaterials 10(10):2082

501 Sathiya Priya R, Geetha D, Ramesh PS (2013) Antibacterial activity of nano-silver capped by $\beta$-cyclodextrin. 502 Carbon Sci Technol 5(1):197-202

503 Selvam S, Gandhi RR, Suresh J, Gowri S, Ravikumar S, Sundrarajan M (2012) Antibacterial effect of novel synthesized sulfated $\beta$-cyclodextrin crosslinked cotton fabric and its improved antibacterial activities with $\mathrm{ZnO}$, $\mathrm{TiO}_{2}$ and $\mathrm{Ag}$ nanoparticles coating. Int J Pharm 434(1-2):366-374

506 Setthayanond J, Sodsangchan C, Suwanruji P, Tooptompong P, Avinc O (2017) Influence of mct- $\beta$-cyclodextrin treatment on strength, reactive dyeing and third-hand cigarette smoke odor release properties of cotton fabric.

508 Cellulose 24:5233-5250

509 Shahidi S, Wiener J (2012) Antibacterial agents in textile industry. In: Bobbarala V (ed) Antimicrobial agents, 510 Chap.19. IntechOpen, pp 387-406

511 Sharma P, Pant S, Rai S, Yadav RB, Sharma S, Dave V (2018) Green synthesis and characterization of silver nanoparticles by Allium cepa L. to produce silver nano-coated fabric and their antimicrobial evaluation. Appl Organomet Chem 32(3):e4146.

514 Sundrarajan M, Rukmani A (2012) Durable antibacterial finishing on organic cotton by inclusion of thymol into 515 cyclodextrin derivative. E-J Chem 9(3):1511-1517

516 Szejtli J (2003) Cyclodextrins in the textile industry. Starch-Stärke 55(5):191-196

517 Szejtli J (2004) Past, present and future of cyclodextrin research. Pure Appl Chem 76(10):1825-1845

518 Szejtli J (2013) Cyclodextrin technology. Vol. 1. Springer Science \& Business Media, 450p

519 Vhanbatte SB, Landage SM, Wasif AI, Dansena B, Karche NV (2017) Nanotechnology for antimicrobial finishing 520 of textiles. Int J Adv Res Eng Appl Sci 6(6):14-23

521 Yang T (2009) Poly(vinyl alcohol)-sulfated $\beta$-cyclodextrin for direct methanol fuel cell applications. Int J Hydrog

522 Energ 34(16):6917-6924 